\title{
ANALISIS KINERJA DAN KEBUTUHAN PETANI GARAM DI KABUPATEN PAMEKASAN SEBAGAI DASAR PENGEMBANGAN DESAIN MODEL SOCIAL LEARNING
}

\author{
Performance and Need Analysis of Salt Farmers in \\ Pamekasan Regency as a Based of Development of the \\ Design of Social Learning Model
}

\author{
*Umi Hanik dan Mutmainah \\ Universitas Trunojoyo Madura \\ JI. Raya Telang, Perumahan Telang Inda, Kabupaten Bangkalan, Jawa Timur 69162, Indonesia \\ Diterima tanggal: 11 Juni 2019 Diterima setelah perbaikan: 2 November 2020 \\ Disetujui terbit: 23 Desember 2020
}

\begin{abstract}
ABSTRAK
Model social learning merupakan suatu pendekatan menggunakan teori observational learning. Model ini telah digunakan oleh Dinas Perikanan Kabupaten Pamekasan untuk meningkatkan kualitas sumber daya manusia. Sayangnya, model social learning belum sepenuhnya berdampak pada peningkatan sumber daya manusia melalui program-program yang dijalankan. Penelitian ini bertujuan untuk melakukan analisis kinerja dan kebutuhan guna mengetahui masalah yang dihadapi petani garam Kabupaten Pamekasan dan menentukan kebutuhan yang harus dimiliki oleh petani garam Kabupaten Pamekasan agar dapat meningkatkan kualitas sumber daya manusia. Penelitian ini merupakan penelitian kualitatif dengan jenis kajian studi kasus. Teknik pengambilan data menggunakan wawancara mendalam ke pihak-pihak terkait, uji keabsahan datanya menggunakan triangulasi sumber dan metode, dan analisis datanya menggunakan metode induktif. Hasil analisis kinerja menunjukkan bahwa terdapat beberapa kendala dari beberapa aspek dalam pelaksanaan program dan analisis kebutuhan menunjukkan bahwa petani garam membutuhkan kompetensi keterampilam dan pengetahuan untuk membuat garam dan kompetensi untuk mengubah pola pikir dengan diimbangi sistem penyampaian informasi yang tidak menyebabkan terputusnya informasi.
\end{abstract}

Kata Kunci: analisis kebutuhan; analisis kinerja; model social learning; petani garam; pola pikir; sumber daya manusia

\begin{abstract}
The social learning model is an approach using observational learning theory. This model has been used by the Pamekasan District Fisheries Office to improve the quality of human resources. Unfortunately, the social learning model has not fully impacted the improvement of human resources through the implemented programs. This study aimed to analyze the performance and needs in order to determine the problems and the needs of the salt farmers in Pamekasan Regency in order to improve the quality of human resources. This research was a case study qualitative research with. Data were collected through in-depth interviews with related parties, their validity were tested using triangulation of sources and methods, and their data analysis were using inductive method. The results of the performance analysis showed that there are several obstacles from several aspects of the program's implementation and needs analysis showed that the salt farmers need the competence of skills and knowledge to produce salt as well as the change of mindset with a balanced information delivery system that does not cause interruption of information.
\end{abstract}

Keywords: need analysis; performance analysis; social learning model; salt farmer; mind set; human resources

\section{PENDAHULUAN}

Kebutuhan komoditas garam dalam negeri tahun 2015 yang mencapai 2,6 juta ton untuk memenuhi kebutuhan di bidang industri dan konsumsi belum dapat dipenuhi oleh produksi garam dalam negeri (Kementerian Perindustrian, 2015). Untuk memenuhi kebutuhan komoditas tersebut, pemerintah mengimpor dari beberapa negara penghasil komoditas garam (Kementerian Kelautan dan Perikanan, 2015). Fakta ini tampak kontradiksi dengan kondisi wilayah geografis Indonesia yang 
merupakan negara kepulauan dimana wilayahnya merupakan laut dengan panjang garis pantai 95.181 km (Kementerian Kelautan dan Perikanan, 2019)_dimana seharusnya menjadi negara penghasil garam yang minimal dapat memenuhi kebutuhan garam dalam negeri. Menurut data Kementerian Kelautan dan Perikanan tahun 2015, luas lahan tambak garam di Indonesia tahun 2015 mencapai 25.830 ha. Berdasarkan data tersebut, jika diperkirakan rata-rata produktivitas garam 133 ton/ha dengan masa panen 29 minggu, maka dengan asumsi tersebut kebutuhan komoditas garam dalam negeri sebesar 2,6 juta ton dapat dipenuhi. Namun kenyataannya, kekayaan luas lahan tersebut belum mampu memenuhi kebutuhan garam dalam negeri, terutama kebutuhan industri karena kualitas garam yang dihasilkan belum bisa memenuhi syarat batas yang sudah diatur dalam regulasi pemerintah-misalnya untuk garam industri pangan harus memiliki kandungan $\mathrm{NaCl}$ minimum 97\% (adbk), Calsium (Ca) maksimum 0,06\%, Magnesium (Mg) maksimum 0,06\%, kadar air (b/b) maksimum $0,5 \%$, bagian yang tidak larut dalam air maksimum $0,5 \%$ dan cemaran logam Kadmium (Cd) maksimum 0,5 mg/Kg, Timbal (Pb) maksium $10 \mathrm{mg} / \mathrm{Kg}$, Raksa $(\mathrm{Hg})$ maksimum 0,1 $\mathrm{mg} / \mathrm{Kg}$ dan Arsen (As) maksimum 0,1 mg/Kg untuk garam beryodium minimum $30 \mathrm{mg} / \mathrm{Kg}$ (Permen Perin Nomor 88/M-IND/PER/10/2014).

Salah satu faktor penyebab rendahnya produktivitas dan kualitas garam adalah kualitas sumber daya manusia (SDM). Beberapa upaya telah dilakukan oleh pemerintah untuk mengatasi permasalahan tersebut yaitu pada akhir tahun 2010 pemerintah pusat mencanangkan "swasembada garam nasional" dan mulai tahun 2011 mengimplementasikan program tersebut melalui Pemberdayaan Usaha Garam Rakyat (PUGAR) berdasarkan Permen KP Nomor PER.41/MEN/2011 tentang Pedoman Pelaksanaan Program Nasional Pemberdayaan Masyarakat Mandiri Kelautan dan Perikanan. Program tersebut dijalankan oleh pemerintah daerah melalui dinas terkait yaitu Dinas Perikanan (untuk tingkat kabupaten sebelumnya Dinas Perikanan dan Kelautan).

Realisasi pelaksanaan program PUGAR dilakukan melalui metode sosialisasi, pelatihan dan pendampingan-dimana metode tersebut merupakan pengejawantahan dari model social learning yang diprakarsai oleh Albert Bandura. Model social learning memberi penekanan bahwa perilaku manusia dipengaruhi oleh lingkungan sekitar sehingga pendekatan yang digunakan dalam model social learning tersebut adalah observational learning (Bandura, 1986)bahwasannya belajar dapat dilakukan melalui sebuah pengamatan yakni sebagian besar upaya belajar manusia terjadi melalui penyajian contoh perilaku (modeling) kemudian melakukan peniruan (imitation) (Pervin, 2010). Ini dapat diartikan bahwa seseorang dapat belajar dengan melihat cara orang atau kelompok orang mereaksi atau merespon sebuah stimulus tertentu. Seseorang juga dapat mempelajari respon-respon baru melalui pengamatan terhadap perilaku contoh terhadap proses teori dari orang lain, misalnya masyarakat lain atau fasilitator (Syah, 2013). Hal itulah yang kemudian menjadi dasar pertimbangan dalam menggunakan model social learning untuk meningkatkan kualitas sumber daya manusia petani garam. Model inipun juga lazim digunakan oleh beberapa instansi pemerintah maupun swasta untuk menjalankan programprogram kerja.

Kabupaten Pamekasan merupakan salah satu daerah pelaksana PUGAR. PUGAR ini dapat diartikan sebagai adanya upaya dari pemerintah untuk meningkatkan kualitas sumber daya manusia petani garam, khususnya dari aspek kompetensipengetahuan maupun ketrampilan. Hal ini juga disebutkan dalam Permen KP Nomor PER.41/ MEN/2011 bahwa PUGAR merupakan salah satu komponen dari Program Nasional Pemberdayaan Masyarakat Mandiri Kelautan dan Perikanan (PNPM Mandiri KP), yang bertujuan untuk mengentaskan kemiskinan melalui peningkatan kemampuan dan pendapatan masyarakat serta penumbuhan usaha kelautan dan perikanan. Namun hal ini menjadi kontradiksi saat sebagian petani garam di Kabupaten Pamekasan masih menggunakan teknologi tradisional untuk membuat garam meskipun telah mendapatkan pelatihan dan pendampingan dari Dinas Perikanan tentang beberapa teknologi alternatif pembuatan garam. Kondisi tersebut mengindikasikan bahwa program-program yang dilakukan melalui pelatihan dan pendampingan belum sepenuhnya berdampak pada peningkatan SDM.

Dalam rangka meningkatkan kualitas sumber daya petani garam khususnya petani garam di Kabupaten Pamekasan tersebut, maka diperlukan sebuah desain model social learning yang sesuai dengan kebutuhan petani garam. Sinergi dengan hal tersebut, penelitian ini bertujuan untuk melakukan analisis kinerja 
guna mengetahui masalah yang dihadapi oleh pemerintah daerah dan petani garam dalam usaha meningkatkan kualitas sumber daya manusia petani garam Kabupaten Pamekasan, dan melakukan analisis kebutuhan guna mengetahui kebutuhan apa saja yang seharusnya dimiliki petani garam Kabupaten Pamekasan agar kualitas sumber daya petani meningkat. Jawaban atas pertanyaan tersebut merupakan hasil penelitian yang selanjutnya dapat menjadi bahan pertimbangan untuk mengembangkan sebuah desain model social learning yang dapat meningkatkan kualitas sumber daya manusia petani garam Kabupaten Pamekasan.

\section{METODOLOGI}

\section{Lokasi dan Waktu Penelitian}

Penelitian dilakukan di tiga kecamatan, yakni Kecamatan Tlanakan, Galis dan Pademawu, Kabupaten Pamekasan, Jawa Timur (Gambar 1). Waktu pelaksanaan penelitian pada bulan September sampai dengan bulan Oktober 2018.

\section{Jenis dan Metode Pengambilan Data}

Penelitian ini menggunakan model pengembangan ADDIE (Analysis, Design, Development, Implementation, and Evaluation) (Dick \& Carey, 1996). Model pengembangan ADDIE terdiri atas 5 tahap yakni 1) analisis (analysis), 2) rancangan (design), 3) pengembangan (development), 4)pelaksanaan (implementation), dan 5) evaluasi (evaluation) (Dick \& Carey, 1996). Sesuai dengan masalah penelitian, penelitian ini difokuskan pada tahap pertama dan kedua yakni tahap analisis (analysis) dan rancangan (design). Tahap pertama terdiri atas dua analisis, meliputi: 1) analisis kinerja (performance analysis), dan 2) analisis kebutuhan (need analysis) (Branch, 2009). Analisis kinerja (performance analysis) digunakan untuk mengetahui masalah yang dihadapi petani garam Kabupaten Pamekasan dan analisis kebutuhan (need analysis) digunakan untuk mengetahui kebutuhan yang harus dimiliki oleh petani garam Kabupaten Pamekasan agar dapat meningkatkan kualitas sumber daya manusia. Tahap kedua yakni merancang model social learning yang sesuai dengan kebutuhan petani garam. Tahap ini menggunakan output pada tahap analisis. Dasar perancangan ini diperoleh dari hasil analisis pada tahap pertama. Berikut bagan model pengembangan ADDIE (Gambar 2).

Pada tahap analysis ini, digunakan pendekatan kualitatif dengan jenis kajian studi kasus. Teknik pengambilan dilakukan melalui wawancara mendalam (in-depth interview) dan dokumentasi (Denzin \& Lincoln, 1994; Sugiono, 2017). Teknik penentuan informan pada penelitian ini menggunakan purposive sampling dan snowball sampling (Yusuf, 2017; Sugiono, 2017).

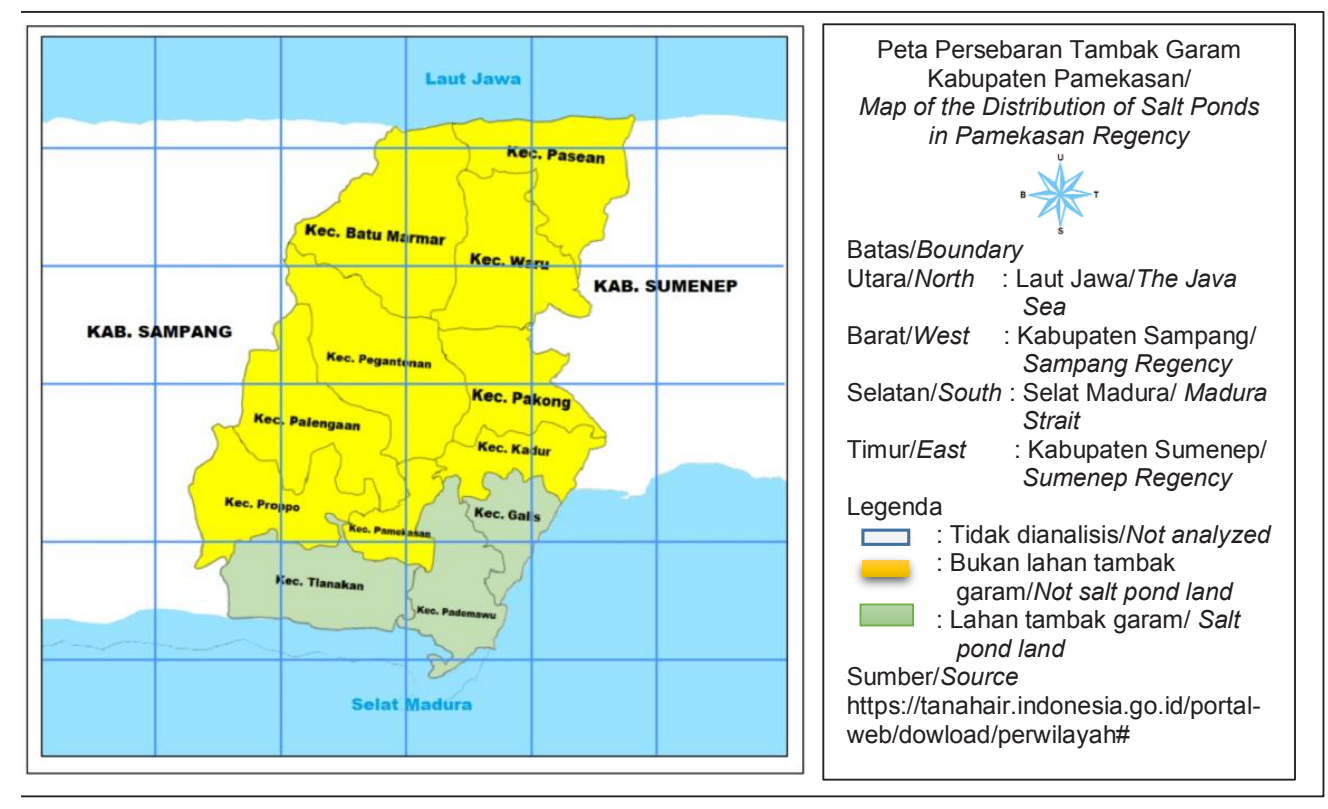

Gambar 1. Peta Kabupaten Pamekasan.

Figure 1. Map of Pamekasan Regency.

Sumber: www.google.com / Source: www.google.com. 


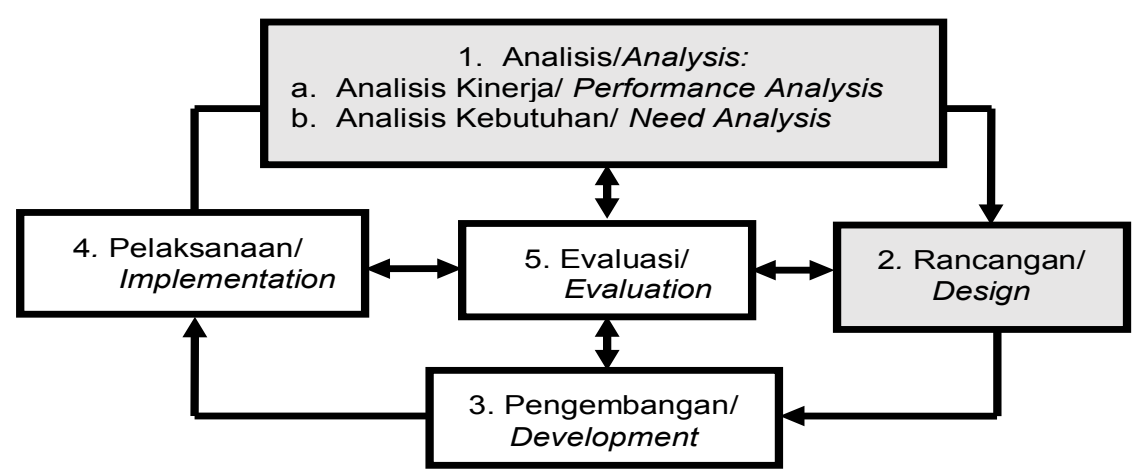

Gambar 2. Model Pengembangan ADDIE.

Figure 2. The Development Model of ADDIE.

Informan dalam penelitian ini adalah Kepala Dinas Perikanan Kabupaten Pamekasan, Kasi Pengelolaan dan Pengembangan Kawasan Budidaya, Kepala Desa Pandeglang, 4 pendamping/penyuluh dari Dinas Perikanan Kabupaten Pamekasan dan 8 petani garam yang berasal dari Kecamatan Pademawu, Galis dan Tlanakan. Berikut daftar nama petani garam, asal kecamatan, status kepemilikan dan teknologi yang digunakan.

\section{Metode Analisis}

Data penelitian pada tahap analisis yakni analisis kinerja dan kebutuhan diolah dan dianalisis menggunakan analisis kualitatif (Neuman, 2000). Analisis metode kualitatif yang dimaksud bersifat kualitatif, yaitu analisisnya dimulai dari fakta atau masalah yang diperoleh melalui pengamatan yang kemudian oleh peneliti disimpulkan (Raco, 2010). Langkah analisisnya meliputi: 1) reduksi data (data reduction), dilakukan untuk mempertajam, memilih, memfokuskan, membuang, dan mengorganisasikan data sehingga kesimpulan akhir dapat digambarkan dan diverifikasikan, 2) display data (data display), menyusun semua informasi yang telah terkumpul yang memungkinkan untuk melakukan penarikan kesimpulan, dan 3) kesimpulan (conclusion) atau verifikasi terhadap data dan informasi yang diperoleh (Huberman \& Miles, 1994; Yusuf, 2017). Ketiga langkah analisis tersebut merupakan segitiga yang saling berhubungan.

Untuk pemeriksaan keabsahan data menggunakan uji kredibilitas dengan triangulasi sumber dan metode (Yusuf, 2017; Sugiono, 2017; Moleong, 2000). Triangulasi sumber dilakukan dengan menggunakan sumber yang banyak dan berbeda untuk informasi yang sama dan triangulasi metode dilakukan dengan menggunakan beberapa metode yang berbeda untuk informasi yang sama.

Tabel 1. Petani Garam Menurut Lokasi, Status Kepemilikan dan Penggunaan Teknologi di Kabupaten Pamekasan. Table 1. Salt Farmers According to Site, Ownership Status and Technology Use in the Pamekasan Regency.

\begin{tabular}{|c|c|c|c|}
\hline $\begin{array}{l}\text { Nama Petani Garam/ } \\
\text { The Name of Salt Farmer }\end{array}$ & $\begin{array}{l}\text { Asal Kecamatan/ } \\
\text { Sub-district }\end{array}$ & $\begin{array}{l}\text { Status Kepemilikan/ } \\
\text { Ownership Status }\end{array}$ & $\begin{array}{l}\text { Penggunaan Teknologi/ } \\
\text { Technology Usage }\end{array}$ \\
\hline Kuswanto & Galis & Milik sendiri/Own & Tradisional/Traditional \\
\hline Maskawi & Galis & Milik sendiri/Own & Tradisional/Traditional \\
\hline Hermanto & Pademawu & Milik sendiri/Own & Geomembran/ Geomembrane \\
\hline Saiful Bahri & Pademawu & Milik sendiri/Own & Geomembran/ Geomembrane \\
\hline Asmu'i & Pademawu & Milik sendiri/Own & Geomembran/ Geomembrane \\
\hline Asmoi & Tlanakan & Sewa/Rent & $\begin{array}{l}\text { Integrasi lahan dan } \\
\text { geomembran/ Corporate farming } \\
\text { and geomembrane }\end{array}$ \\
\hline Hendri & Tlanakan & Sewa/Rent & $\begin{array}{l}\text { Integrasi lahan dan } \\
\text { geomembran/ Corporate farming } \\
\text { and geomembrane }\end{array}$ \\
\hline Alfan & Tlanakan & Sewa/Rent & $\begin{array}{l}\text { Integrasi lahan dan } \\
\text { geomembran/ Corporate farming } \\
\text { and geomembrane }\end{array}$ \\
\hline
\end{tabular}




\section{HASIL DAN PEMBAHASAN}

\section{Gambaran Umum}

Petani garam rakyat di Kabupaten Pamekasan terbagi menjadi tiga status, yakni: 1) pemilik penggarap yaitu pemilik lahan tambak garam yang menggarap sendiri, biasanya petani ini memiliki luasan lahan tambak garam yang relatif kecil, 2) penyewa penggarap yaitu petani yang menggarap lahan tambaknya dari hasil menyewa dengan sistem sewa berdasarkan musim garam tidak berpatokan pada tahun berjalan, dan 3) penggarap bagi hasil yaitu petani garam yang melakukan usaha garam yang melakukan usaha garam menggunakan sistem bagi hasil dengan pemilik tambaknya baik dengan pola $1 / 3$ untuk petambak dan $2 / 3$ untuk pemilik dengan ketentuan semua biaya operasional produksi ditanggung pemilik atau $1 / 2$ untuk petani penggarap dan $1 / 2$ untuk pemilik dengan ketentuan pemilik tidak menanggung biaya operasional produksi. Banyaknya petani garam berdasarkan status di tiga kecamatan tersebut dapat dilihat pada Tabel 2.

Secara umum, petani garam dengan tiga status seperti dijelaskan di atas masuk dalam kategori petani penggarap—biasanya memiliki kondisi ekonomi menengah ke bawah. Petani penggarap mayoritas di Kabupaten Pamekasan adalah petani penggarap bagi hasil yakni sebesar $70 \%$. Keterbatasan dalam kepemilikan lahan dan modal atau biaya produksi memaksa mereka menjadi petani penggarap bagi hasil. Petani penggarap bagi hasil biasanya didominasi dari daerah luar Kabupaten Pamekasan misalnya Sumenep dan Gresik dan biasanya datang menjelang musim produksi garam. Petani penyewa penggarap, selain berasal dari daerah setempat, mereka juga berasal dari luar daerah sama seperti petani garam bagi hasil yang biasanya datang "musiman" atau "dadakan". Perbedaan antara petani penggarap bagi hasil dengan petani penyewa penggarap adalah pada kepemilikan modal. Modal petani penggarap bagi hasil berasal dari pemilik lahan dan modal petani penyewa penggarap berasal dari petani itu sendiri. Persentase petani penyewa penggarap ini sebesar $16 \%$. Petani garam dengan persentase terkecil adalah petani pemilik penggarap yakni sebesar $14 \%$. Lahan petani pemilik penggarap biasanya diperoleh dari warisan dan pembelian yang tidak terlalu luas. Modal petani pemilik penggarap ini berasal dari dirinya sendiri.

\section{Analisis Kinerja (Performance analysis)}

Berdasarkan hasil wawancara dengan para informan tentang kinerja petani garam di Kabupaten Pamekasan dapat diidentifikasi berbagai masalah yang muncul dapat dilihat pada Tabel 3.

Masalah pertama adalah keengganan sebagian petani garam dalam menggunakan teknologi geomembran untuk membuat garam. Salah satu faktor penyebabnya adalah karena rasa pahit (getir) pada garam yang dihasilkan. Menurut Kuswanto ${ }^{1}$.

"...jika menggunakan membran, garam yang dihasilkan warnanya lebih putih dan bersih tapi rasanya pahit (getir). Rasa pahitnya itu berasal dari bahan dasar membran itu sendiri yaitu dari bahan plastik. Garam yang pahit itu merupakan garam yang tidak sehat."

Hal tersebut dibantah oleh pihak Dinas Perikanan Kabupaten Pamekasan, Nurul Widiastuti².

"...rasa pahit (getir) di garam sebenarnya disebabkan cara pembuatan garam yang tidak mengikuti Standar

Tabel 2. Petani Garam Rakyat Kabupaten Pamekasan.

Table 2. Folk's Salt Farmer in Pamekasan Regency.

\begin{tabular}{lccc}
$\begin{array}{l}\text { Kecamatan/ } \\
\text { Sub Distric }\end{array}$ & $\begin{array}{c}\text { Pemilik Penggarap/ } \\
\text { Owner }\end{array}$ & $\begin{array}{c}\text { Penyewa Penggarap/ } \\
\text { Tenant }\end{array}$ & $\begin{array}{c}\text { Bagi Hasil/Mantong/ } \\
\text { Profit Sharing }\end{array}$ \\
\cline { 1 - 3 } Galis & 81 & 172 & 542 \\
Pademawu & 118 & 59 & 470 \\
Tlanakan & 2 & 0 & 19 \\
Total/Total & 201 & 231 & 1.031 \\
\hline
\end{tabular}

Sumber: Dinas Perikanan dan Kelautan Kabupaten Pamekasan, 2015 /

Source: Ministry of Maritim Affairs and Fisheris Pamekasan Regency, 2015 
Tabel 3. Kinerja Petani Garam.

Table 3. The Salt Farmer's Performance.

\begin{tabular}{|c|c|}
\hline Informan/Informan & Kinerja/Performance \\
\hline Kuswanto & $\begin{array}{l}\text { - Adanya anggapan bahwa garam yang menggunakan teknologi geo membran memiliki } \\
\text { rasa pahit (getir) sehingga tidak mau menggunakan teknologi geomembran/There is an } \\
\text { assumption that salt using Geo-membrane technology has a (bitter) taste so that it does } \\
\text { not want to use that technology. }\end{array}$ \\
\hline \multirow[t]{2}{*}{ Dinas Perikanan } & $\begin{array}{l}\text { - Pembuatan garam tidak sesuai SOP menghasilkan garam yang pahit (getir)/ } \\
\text { In making salt which is not in accordance with SOP produces so bitter salt }\end{array}$ \\
\hline & - Sebagian petani sulit untuk diberi pelatihan/Some farmers got so difficult to be trained. \\
\hline Hermanto & $\begin{array}{l}\text { - Kekhawatiran integrasi lahan adalah ukuran tanah tidak kembali seperti semula/ } \\
\text { The worry of land integration is that the size of the land does not return to normal }\end{array}$ \\
\hline \multirow[t]{2}{*}{ Asmu'i } & $\begin{array}{l}\text { - Adanya informasi bahwa pembuatan garam menggunakan teknologi geomembran } \\
\text { rasanya pahit namun tetap menggunakan teknologi tersebut karena lebih bersih/There } \\
\text { is information that making salt using geo-membrane technology tastes bitter but still uses } \\
\text { this technology because it is cleaner }\end{array}$ \\
\hline & $\begin{array}{l}\text { - Sering mengikuti pelatihan dan penyampai informasi ke petani garam lain/Often attend } \\
\text { training and provide information to other salt farmers }\end{array}$ \\
\hline Kepala Desa & $\begin{array}{l}\text { Tambak garam yang diintegrasi bisa dilakukan pengukuran ulang sesuai kepemilikan/ } \\
\text { The integrated salt pond can be re-measured according to ownership. }\end{array}$ \\
\hline Saiful Bahri & $\begin{array}{l}\text { Tidak menyetujui integrasi lahan karena tingkat produktivitas tiap lahan berbeda sehingga } \\
\text { prosentasi pembagian hasil juga harus berbeda/Do not agree with land integration because } \\
\text { the productivity level of each land is different so that the percentage of profit sharing must } \\
\text { also be different. }\end{array}$ \\
\hline
\end{tabular}

Operasional Procedure (SOP), yaitu petani tidak mau membuang air sisa panen garam sehingga menyebabkan kadar magnesium tinggi. Tingginya kadar magnesium itulah yang menyebabkan munculnya rasa pahit pada garam.

\section{Muzanni ${ }^{3}$ menambahkan:}

"Keengganan petani membuang air sisa panen garam karena menurutnya jika air tersebut dicampur dengan air tua akan mempercepat proses proses penuaan air. Harusnya petani melakukan sesuai SOP produksi garam yaitu dengan cara mengembalikan sisa air tua ke boussem (tempat penampungan air muda), sehingga bisa memperkecil kandungan Magnesium."

Menurut Fauziyah ${ }^{4}$ mengatakan bahwa:

"Hasil produksi garam yang pahit (getir) selama proses produksi menggunakan geomembran dikarenakan tidak ada penurunan dan pengendapan mineral-mineral yang diserap oleh tanah sehingga mineral-mineral tersebut tetap mengendap dan tercampur di media geomembran."

Namun, sebagian petani garam lain tetap menggunakan teknologi geomembran meskipun menganggap bahwa pembuatan garam dengan teknologi tersebut menyebabkan rasa pahit (getir) pada garam. Alasan penggunaan tenologi tersebut karena garam yang dihasilkan lebih banyak, lebih bersih, dan mempercepat penuaan air sehingga mempercepat masa panen. Seperti diungkapkan oleh Asmu'i ${ }^{5}$ bahwa:

"Jika menggunakan geomembran rasanya pahit tapi karena hasilnya lebih banyak dan bersih dan panen lebih cepat maka saya tetap menggunakan membran."

Seperti diungkapkan oleh Bestekin (2019), bahwa setiap garam pada umumnya mengandung magnesium pada kristalnya. Kandungan magnesium relatif tinggi pada garam yang dihasilkan oleh tambak garam dan kandungan

\footnotetext{
${ }^{2}$ Ir. Nurul Widiastuti (dalam penelitian ini disebut tanpa gelar) adalah Kepala Dinas Perikanan Kabupaten Pamekasan (Wawancara dilakukan pada tanggal 4 Oktober 2018)

${ }^{3}$ Muzanni, S.H., M.Si. (dalam penelitian ini disebut tanpa gelar) adalah Kasi Pengelolaan dan Pengembangan Kawasan Budidaya (Wawancara dilakukan pada tanggal 4 Oktober 2018)

${ }^{4}$ Fauiyah (dalam penelitian ini disebut tanpa gelar) adalah Pendamping dan Penyuluh Pengelolaan dan Pengembangan Kawasan ${ }^{5}$ Budidaya (Wawancara dilakukan pada tanggal 4 Oktober 2018)

Petani garam dari Kecamatan Pademawu (Wawancara dilakukan pada tanggal 15 Oktober 2018)
} 
tersebut mempengaruhi rasa garam yaitu menyebabkan rasa pahit getir. Berdasarkan hasil penelitian, kandungan magnesium dan zat pereduksi tersebut dapat dikurangi hingga 0,016\% wt dan 2,65 ppm (Saksono, 2002).

SOP pembuatan garam yang tepat melalui teknologi geomembran tersebut telah disampaikan kepada petani garam melalui kegiatan sosialisasi, pelatihan dan bimtek. Namun sebagian petani yang memproduksi garam menggunakan teknologi geomembran tidak melakukan sesuai dengan SOP yang diberikan yang berdampak pada garam yang dihasilkan. Ada 2 (dua) faktor yang diprediksi menjadi penyebab, pertama, informasi tentang SOP pembuatan garam sebagian hilang karena penyampaian informasi secara berantai. Sosialisasi dan pelatihan yang diselenggarakan oleh Dinas Perikanan Kabupaten Pamekasan tidak melibatkan seluruh petani garam dan hanya melibatkan perwakilan dari kelompok petani. Perwakilan kelompok petani garam inilah yang meneruskan informasi dari penyuluh Dinas Perikanan dan Kelautan Kabupaten Pamekasan hingga ke petani garam lainnya. Seperti dijelaskan oleh Asmu'i bahwa:

“...biasanya saya yang mengikuti pelatihan di dinas kemudian saya menyampaikan ke petani garam yang lain tentang informasi yang telah saya terima."

Prediksi kedua yakni, petani garam memiliki pengetahuan SOP tentang pembuatan garam menggunakan geomembran yang lengkap namun mengabaikan 1 (satu) langkah dalam SOP yakni mencampur air sisa panen dengan air muda dengan pencampuran tersebut dianggap mempercepat proses penuaan air garam. Seperti dikatakan oleh Asmu'i bahwa:

“...air sisa panen yang dicampur dengan air muda akan mempercepat penuaan air garam. Kalau sesuai materi pelatihan, seharusnya air sisa panen dibuang semua."7

Faktor penyebab lain enggannya petani menggunakan teknologi geomembran adalah karena masalah biaya. Kuswanto mengatakan bahwa:

\section{"...harga geomembran juga mahal makanya saya masih memakai cara tradisional "8}

Pada kondisi normal (cuaca yang mendukung), untuk masa panen 12 hari dengan luas lahan $8 \mathrm{~m} \times 40 \mathrm{~m}$, cara tradisional dapat menghasilkan 4 ton garam dan dengan menggunakan teknologi geomembran dapat menghasilkan 6 ton garam. Harga jual garam yang diproduksi menggunakan teknologi geomembran pun lebih tinggi yakni antara Rp275.000,00 - Rp350.000,00 dibanding produksi garam menggunakan cara tradisional yakni sekitar Rp200.000,00 - Rp250.000,00.

Harga jual lebih tinggi dengan penggunaan teknologi geomembran, namun dengan kondisi ekonomi menengah ke bawah-harus menyiapkan modal awal sekitar Rp2.000.000,00 - Rp4.000.000,00 (untuk per petak tambak dengan ukuran $8 \mathrm{~m} \times 40 \mathrm{~m}$ ) untuk pembelian geomembran menjadi salah satu alasan petani tidak menggunakan teknologi geomembran. Hal lain yang seharusnya menjadi pemicu penggunaan geomembran selain hasil produksi yang lebih banyak dan harga jual yang lebih tinggi dibanding produksi garam menggunakan cara tradisional adalah penggunaan geomembran yang tidak sekali pakai. Geomembran dengan ketebalan 300 mikron dapat digunakan hingga 1-3 tahun dan geomembran dengan ketebalan 500 mikron dapat digunakan hingga 3-4 tahun.

Kedua, keengganan sebagian petani garam melakukan integrasi lahan (corporate farming). Integrasi lahan adalah penggabungan lahan garam rakyat yang berorientasi pada laba/keuntungan dimana pengelolaannya dapat dilakukan oleh kelompok petani, koperasi atau BUMDes garam (Poerwadi dalam Tirto, 2018; Baekhaki, Kinseng \& Soetarto, 2018). Integrasi lahan ini dapat dilakukan jika dalam satu area lahan luasannya minimum sekitar $15 \mathrm{Ha}$. Lahan tersebut dibagi untuk lahan brine water tank (tandon air laut), lahan pembenihan, gulir garam, sampai lahan untuk kristalisasi. Sulitnya melakukan integrasi lahan tersebut disebabkan beberapa masalah yang sifatnya pribadi, pertama, pembagian lahan tambak garam menjadi petak yang lebih kecil

\footnotetext{
${ }^{6}$ Wawancara dilakukan pada tanggal 15 Oktober 2018 ${ }^{7}$ Ibid

${ }^{8}$ Wawancara dilakukan pada tanggal 15 Oktober 2018
} 
karena berasal dari warisanyang menimbulkan kekawatiran adanya pergeseran luas lahan tambak garam yang dimiliki jika dilakukan integrasi, seperti diungkapkan oleh Hermanto ${ }^{9}$ bahwa:

“...kalau lahan digabung, takutnya luas lahan menjadi berbeda, tidak kembali seperti semula."

Kasus di atas bukannya tidak ada solusi. Menurut Ibnu Hajar ${ }^{10}$,

"Kasus integrasi lahan tersebut sebenarnya dapat diselesaikan dengan melakukan pengukuran ulang jika suatu saat berpindah kepemilikan atau tidak digunakannya sistem integrasi lahan lagi dalam membuat garam."

Terkait pengukuran ulang ini, belum pernah dilakukan sosialisasi sehingga pengetahuan dan pemahaman petani garam terkait pengukuran ulang ini rendah bahkan belum ada sama sekali.

Penyebab keengganan petani garam untuk melakukan integrasi lahan yang kedua adalah tingkat produktifitas lahan yang berbeda-beda. Jadi meskipun terpenuhi syarat batas minimal luasan lahan yakni 15 ha dalam satu hamparan, petani tidak bersedia melakukan integrasi lahan. Seperti dikatakan Saiful Bahri'1"

"...setiap lahan memiliki tingkat produktifitas yang berbeda-beda. Ada lahan yang tingkat produktifitasnya tinggi dan ada pula yang rendah sehingga petani yang memiliki lahan dengan tingkat produktifitas tinggi akan merasa rugi."

Petani garam yang memiliki lahan dengan produktifitas tinggi meminta ada pembagian hasil yang proporsional. Masalah tersebut hingga penelitian ini selesai dilakukan belum ada penyelesaiannya.

Ketiga, terkait motif menjadi petani garam. Motif merupakan salah satu dari 5 (lima) aspek stimulus kategori kompetensi yang dapat dilakukan melalui penyajian contoh perilaku (modeling) yang dilakukan secara mandiri maupun terprogram (Hanik \& Mutmainah, 2018). Kelima aspek tersebut adalah: 1) pengetahuan (knowledge), 2) keterampilan (skill), 3) konsep diri (self concept), 4) pribadi/ sifat (traits), dan 5) motif (motives) (Spencer \& Spencer, 1993: 9-11). Rata-rata motif petani garam yaitu, pertama, sebatas untuk memenuhi kebutuhan fisiologis (physiological needs). Kebutuhan fisiologis (physiological needs) adalah kebutuhan akan sandang (pakaian), pangan (makanan), dan papan (tempat tinggal) (Maslow, 1994). Kebutuhan terhadap pendidikan hanya sebatas pada kemampuan baca dan tulis atau pemenuhan terhadap syarat pencarian kerja yang kebanyakan untuk pekerjaan buruh pabrik. Asmu'i mengatakan bahwa motif menjadi petani garam adalah agar bisa menghidupi anak istri ${ }^{12}$, menurut Saiful Bahri memiliki motif agar bisa buat rumah $^{13}$, dan Kuswanto mengatakan bahwasannya motifnya adalah agar bisa menyekolahkan anak, sehingga memiliki nasib lebih baik dengan mudah mencari kerja."14 Dengan motif tersebut, petani garam berada pada zona nyaman sehingga sulit mengalami peningkatan.

Motif kedua yaitu meneruskan usaha keluarga. Seperti dikatakan oleh Asmu'i'15, Asmoi ${ }^{16}$ dan Maskawi ${ }^{17}$ bahwa dengan adanya lahan tambak garam yang dimiliki oleh keluarga membuat mereka harus mengelola lahan tersebut. Hal ini sinergi dengan penelitian Hotimah (2019) bahwa pemberian warisan tambak garam oleh orang tua merupakan dorongan petani garam untuk tetap terus melakukan pekerjaan menjadi petani garam.

Motif ketiga, keterpaksaan karena tidak ada pekerjaan lain selain menjadi petani garam seperti dikatakan oleh Saiful Bahri ${ }^{18}$ Tidak adanya keahlian lain menjadikan pekerjaan petani garam satusatunya pilihan. Salah satu faktor pemicunya adalah rendahnya pendidikan formal para petani garam (Hotimah, 2019). Anggapan yang muncul yakni tidak ada pendidikan formal terkait pergaraman.

\footnotetext{
${ }^{9}$ Petani garam dari Kecamatan Pademawu (Wawancara dilakukan pada tanggal 15 Oktober 2018)

${ }^{10}$ Klebun (Kepala Desa) Desa Pandeglang Kecamatan Pademawu (wawancara dilakukan pada tanggal 15 Oktober 2015)

${ }^{11}$ Petani garam dari Kecamatan pademawu (wawancara dilakukan pada tanggal 15 Oktober 2018)

${ }^{12}$ Wawancara dilakukan pada tanggal 15 Oktober 2018

${ }^{13}$ Wawancara dilakukan pada tanggal 15 Oktober 2018

${ }^{14}$ Wawancara dilakukan pada tanggal 20 September 2018

${ }^{15}$ Wawancara dilakukan pada tanggal 15 Oktober 2018

${ }^{16}$ Petani garam dari Kecamatan Tlanakan (wawancara dilakukan pada tanggal 4 Oktober 2018)

${ }^{17}$ Petani garam dari Kecamatan Galis (wawancara dilakukan pada tanggal 20 September 2018)
} 
Keterampilan membuat garam cukup diperoleh dari pengalaman di lapangan.

Motif keempat, tergiur dengan harga garam yang saat ini naik seperti dikatakan Hendri ${ }^{19}$. Meskipun sebenarnya dari sisi pemasaran lemah yakni tidak memiliki posisi tawar yang kuat karena adanya kebutuhan mendesak sehingga cenderung langsung menjual garam saat panen (Salim, 2016). Motif kelima, peniruan (modeling) dari masyarakat sekitar yang mayoritas bekerja sebagai petani garam seperti dikatakan oleh Alfan ${ }^{20}$.

Identifikasi dan klarifikasi masalah keempat yaitu tertutupnya sebagian petani garam terhadap informasi atau pengetahuan baru. Nurul Widiastuti mengatakan,

"Sebagian petani disini masih
sulit untuk diberi pelatihan. Mereka
menganggap dirinya paling paham dalam
membuatgaram. Terkadang berkata "kalian
siapa, apakah bisa membuat garam kok
mau mengajari kami membuat garam?",
sehingga beberapa program kami belum
tersampaikan di beberapa wilayah."21

Petani garam yang memiliki karakter ini mengadaptasi pendapat Bouwsma (1989) dan Wahyudi (2015) memiliki harga diri yang tinggi seperti karakter yang dimiliki masyarakat Madura pada umumnya. Petani garam menolak untuk diberi pelatihan karena merasa "cukup" atas pengetahuan yang dimiliki yang diperoleh secara turun temurun dari leluhur. Hal tersebut berdampak pada praktik pembuatan garam dengan hanya menggunakan teknologi sederhana, yaitu secara tradisional yang akhirnya berdampak pada kualitas maupun tingkat produksi. Petambak garam perlu membuka diri dan melakukan alih teknologi tepat guna untuk mampu bersaing dan meningkatkan kualitas produksi di pasaran sehingga dapat meningkatkan pendapatan.

\section{Analisis Kebutuhan (Need Analysis)}

Mencermati hasil dari analisis kinerja tersebut, kebutuhan yang dipandang perlu oleh petani garam Kabupaten Pamekasan untuk meningkatkan kualitas sumber daya manusia dapat diklasifikasi ke dalam dua aspek. Kedua aspek tersebut adalah: 1) aspek kompetensi/kemampuan, dan 2) aspek sistem manajemen penyampaian informasi dan pengelolaan bantuan.

\section{Aspek Kompetensi}

Selain kompetensi pengetahuan dan keterampilan tentang cara membuat garam, ada kompetensi lain yang dibutuhkan petani garam Kabupaten Pamekasan, yakni kompetensi untuk mengubah pola pikir (mind set). Kompetensi tersebut dapat diperoleh melalui penyajian contoh perilaku (modelling) terprogram dimana dilakukan secara terencana oleh seseorang, masyarakat, dan fasilitator. Penyajian modeling secara terprogram bisa dilakukan melalui diskusi, sosialisasi, pendidikan, pelatihan, dan media lainnya (Hanik \& Mutmainah, 2018). Kompetensi tersebut diberikan kepada, pertama, petani garam yang memiliki motif atau orientasi menjadi petani garam untuk kebutuhan fisiologi (physiological needs) semata. Petani garam diupayakan dapat menaikkan motif ke dalam tingkatan yang lebih tinggi, misalnya kebutuhan akan penghargaan (esteem need) seperti kebutuhan akan status, ketenaran, kompetensi, prestasi, dan bahkan bisa pada level yang tertinggi, yakni kebutuhan aktualisasi diri (self actualization needs). Kedua, untuk petani garam yang masih belum terbuka terhadap informasi atau teknologi baru yang masuk. Hal ini bisa jadi bukanlah suatu hal yang mudah karena terkait dengan karakter orang Madura yang sangat menjunjung tinggi kehormatan dan harga diri. Petani garam diupayakan terbuka terhadap informasi atau teknologi baru tanpa mengubah karakter orang Madura, yakni kehormatan dan harga diri.

\section{Aspek Manajemen Penyampaian Informasi dan Pengelolaan Bantuan}

Selain melalui diskusi, sosialisasi, pendidikan, dan pelatihan, modelling secara terprogram dapat dilakukan melalui FGD (Focus Group Discussion). Dalam kasus ini, pelatihan dilakukan untuk penyampaian program yang akan dijalankan

\footnotetext{
${ }^{18}$ Wawancara dilakukan pada tanggal 15 Oktober 2018

${ }^{19}$ Petani garam dari Kecamatan Tlanakan (wawancara dilakukan pada tanggal 4 Oktober 2018)

${ }^{20}$ Petani garam dari Kecamatan Tlanakan (wawancara dilakukan pada tanggal 4 Oktober 2018)

${ }^{21}$ Wawancara dilakukan pada tanggal 4 Oktober 2018
} 
dan diperuntukkan secara umum bagi petani garam dan secara khusus bagi petani garam yang masih enggan menggunakan teknologi baru untuk pembuatan garam. Selain itu pelatihan juga dilakukan untuk memberikan bimbingan teknis tentang tata kelola bantuan yang diberikan oleh pemerintah kepada kelompok petani garam. Namun, ada beberapa pertimbangan dalam melakukan pelatihan, yakni, pertama, menghindari penyampaian informasi secara berantai. Upaya pencegahan (preventive) yang dapat dilakukan adalah: 1) pelatihan dapat dilakukan di setiap kecamatan dengan melibatkan seluruh petani garam, 2) mengefektifkan pelatihan dengan menentukan perwakilan kelompok yang hadir, yang memiliki kriteria mampu menyampaikan informasi kepada petani garam lainnya, 3) seluruh petani garam diharapkan menerima modul yang sama seperti petani garam yang menjadi wakil untuk mengikuti pelatihan. Modul diupayakan menarik dan dapat memfasilitasi petani garam yang tidak bisa membaca atau menulis melalui gambar. Upaya pencegahan tersebut didukung dengan pendampingan-pendampingan pasca pelaksanaan program.

Modelling secara terprogram yang lain yakni FGD dilakukan untuk mengumpulkan informasi atau masukan yang bersifat lokal atau spesifik terkait permasalahan integrasi lahan pertambangan garam. Dengan terjaringnya informasi tersebut, permasalahan integrasi lahan pertambangan garam diharapkan dapat ditemukan solusi terbaik untuk mengatasi masalah tersebut.

\section{Desain Model Social Learning}

Perlunya kompetensi pengetahuan dan ketrampilan tentang pembuatan garam sesuai dengan SOP dan juga kompetensi untuk mengubah pola pikir (mind set) sehingga meningkatkan motif menjadi petani garam, menjadi dasar pengembangan SDM petani garam. Pengembangan sumber daya manusia atau Human Resources Development (HRD) menurut Notoatmodjo (1998) adalah suatu proses perencanaan pendidikan, pelatihan, dan pengelolaan tenaga atau karyawan untuk mencapai hasil yang maksimal. Model Social learning sebagai pendekatan dalam mengembangkan kualitas SDM petani garam, memiliki konsep dasar bahwa perilaku manusia di pengaruhi lingkungannya. Pertama, pada dasarnya manusia mempunyai potensi, minat dan bakat berdasarkan potensi bawaan dan lingkungan, hal inilah yang membentuk pola-pola perilaku yang menjadi ciri-ciri khas kepribadiannya. Kedua, manusia mampu merefleksikan tingkah lakunya sendiri, mengatur dan mengontrol perilakunya sendiri. Ketiga, yaitu bahwa perilaku manusia adalah melalui proses belajar. Keempat yaitu manusia mampu mempengaruhi perilaku orang lain, begitu juga sebaliknya bahwa perilaku dirinya juga bisa dipengaruhi oleh perilaku orang lain (Koeswara, 1988). Selain pendidikan, pelatihan dan pengelolaan tenaga atau karyawan untuk pengembangan SDM, sosialisasi juga dapat dijadikan alternatif pengembangan SDM menggunakan pendekatan dalam model social learning. Sosialisasi bertujuan memberi pengetahuan yang berhubungan dengan nilai dan norma dalam masyarakat, membantu individu untuk berpartisipasi dengan lingkungan, dan menciptakan integrasi masyarakat (Idi, 2013).

Belajar menggunakan pendekatan model social learning dapat dilakukan melalui sebuah pengamatan yakni melalui penyajian contoh perilaku (modeling) kemudian melakukan peniruan (imitation) (Pervin, 2010). Seseorang dapat belajar dengan melihat cara orang atau kelompok orang mereaksi atau merespon sebuah stimulus tertentu. Seseorang juga dapat mempelajari respon-respon baru melalui pengamatan terhadap perilaku contoh terhadap proses teori dari orang lain, misalnya masyarakat lain atau fasilitator (Syah, 2013).

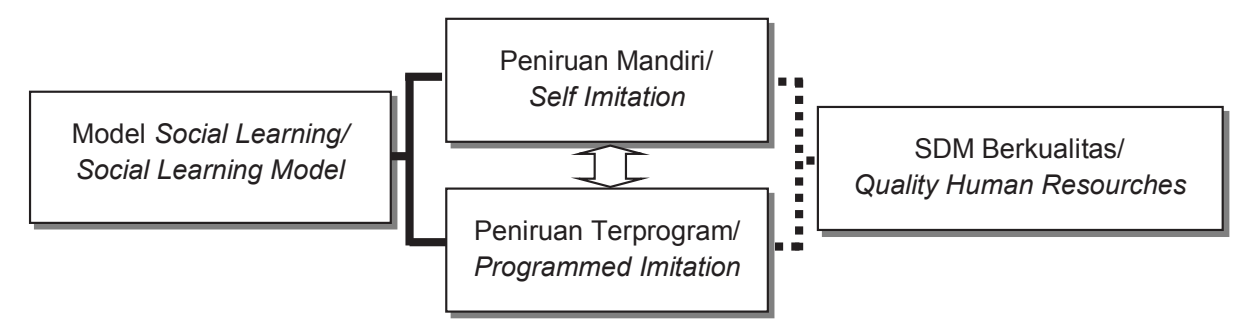

Gambar 3. Model Social Learning untuk Pengembangan SDM Petani Garam di Kabupaten Pamekasan.

Figure 3. Social Learning Model for Human Resource Development for Salt Farmers in Pamekasan Regency. 
Gambar 3 merupakan desain model social learning untuk pengembangan SDM petani garam di Kabupaten Pamekasan.

Peniruan mandiri dilakukan oleh individu secara langsung ataupun tidak langsung kepada individu lain atau suatu kelompok. Dalam hal ini, individu yang akan ditiru dapat dimanipulasi atau diciptakan. Peniruan terprogram dapat dilakukan oleh lembaga atau instansi seperti pemerintah, Lembaga Swadaya Masyarakat (LSM), Akademisi dll melalui pelatihan dan sosialisasi. Kompetensi yang diberikan bukan hanya pengetahuan dan keterampilan membuat garam namun juga kompetensi untuk mengubah pola pikir (mind set).

\section{KESIMPULAN DAN REKOMENDASI KEBIJAKAN}

\section{Kesimpulan}

Berdasarkan pembahasan penelitian dapat disimpulkan bahwa masalah yang dihadapi oleh Pemerintah Daerah Kabupaten Pamekasan dalam upayanya meningkatkan kualitas sumber daya manusia petani garam adalah: 1) kegiatan sosialisasi dan pelatihan di sebagian wilayah kecamatan bisa dikatakan belum tuntas sehingga muncul isu negatif seperti pahitnya produk garam yang dihasilkan menggunakan teknologi geomembran. Hal ini menjadi penting karena menyebabkan sebagian petani garam belum mengimplementasikan program dari pemerintah meskipun telah tergabung dalam kelompok petani garam binaan. Bahkan, meskipun telah menggunakan teknologi geomembran, petani garam tetap beranggapan bahwa produk garam yang dihasilkan menggunakan teknologi geomembran tersebut memiliki rasa pahit yang penyebabnya berasal dari bahan plastik geomembran.

Kedua, kondisi ekonomi petani penggarap yang menengah ke bawah menjadi salah satu alasan tidak digunakannya geomembran. Modal awal yang dibutuhkan untuk pembelian geomembran memberatkan petani meskipun penggunaan geomembran untuk beberapa musim panen.

Ketiga, belum ada titik temu solusi untuk permasalahan program integrasi lahan di beberapa wilayah kecamatan meskipun di beberapa wilayah tersedia lahan yang cukup untuk memenuhi persyaratan integrasi lahan. Penyebabnya diantaranya kekhawatiran petani garam terhadap lahan kemungkinan akan berkurang dan pembagian hasil yang tidak proporsional disebabkan tingkat produktivitas lahan yang berbeda-beda.

Keempat, motif menjadi petani garam terbatas untuk memenuhi kebutuhan fisiologis. Kebutuhan tersebut seperti sandang (pakaian), pangan (makanan), dan papan (tempat tinggal). Kebutuhan terhadap pendidikan hanya sebatas untuk memiliki kemampuan baca dan tulis dan pemenuhan syarat mencari kerja seperti bekerja menjadi buruh. Dengan motif tersebut, petani berada dalam zona nyaman sehingga muncul kepuasan dini.

Kelima, keengganan sebagian petani garam menerima teknologi atau informasi baru yang diberikan oleh penyuluh/pendamping dari Dinas Perikanan Kabupaten Pamekasan. Hal tersebut disebabkan oleh pola pikir petani garam terhadap kemampuan yang dimilikinya, yakni: 1) merasa dirinya telah memiliki kemampuan membuat garam, dan 2) tidak perlu dan/atau akan ada perubahan cara dalam membuat garam.

Berdasarkan hasil dan pembahasan pada analisis kinerja disimpulkan tentang kebutuhan yang dipandang perlu untuk petani garam di Kabupaten Pamekasan yakni: 1) kompetensi pengetahuan dan ketrampilan tentang pembuatan garam sesuai dengan SOP dan kompetensi untuk mengubah pola pikir (mind set) sehingga meningkatkan motif menjadi petani garam, dan 2) manajemen penyampaian informasi dan manajemen pengelolaan bantuan yang sesuai dengan permasalahan dan kondisi petani garam Kabupaten Pamekasan.

\section{Rekomendasi Kebijakan}

Model social learning yang telah diimplementasikan untuk menjalankan setiap program memiliki strategi yang berbeda. Untuk itu pemerintah sebagai pembuat kebijakan sebaiknya mempertimbangkan setiap strategi yang membutuhkan model social learning agar tujuan program dapat tercapai. Dalam penelitian ini ada beberapa rekomendasi diantaranya: pertama, dalam meningkatkan kualitas sumber daya manusia petani garam sebaiknya fokus social learning tidak hanya pada pengetahuan dan keterampilan tentang cara membuat garam semata namun juga pada perubahan pola pikir (mind set). Kebijakan ini akan berdampak positif pada perubahan pola pikir sehingga petani garam yang semula menolak teknologi atau informasi baru menjadi terbuka 
terhadap teknologi atau informasi tersebut. Kedua, dalam rangka meningkatkan motivasi untuk meningkatkan kompetensi petani garam, pemerintah daerah dapat menyelenggarakan kompetisi pemilihan petani garam berprestasi secara kontinu. Ketiga, menghindari sistem penyampaian informasi secara berantai mengingat dampak yang muncul tidak tersampaikannya program secara keseluruhan bahkan muncul isu yang sifatnya negatif terhadap implementasi suatu program. Keempat, dalam rangka menyelesaikan permasalahan integrasi lahan, dilakukan FGD (Focus Group Discussion) agar permasalahan tiap petani diketahui. Kelima, mengaktifkan peran dan fungsi kelompok tani bukan hanya terkait peningkatan kompetensi namun juga untuk peningkatan kesejahteraan melalui pengelolaan bantuan yang terpadu.

\section{UCAPAN TERIMA KASIH}

Penulis mengucapkan terima kasih kepada semua pihak yang telah membantu dan mendukung selama pelaksanaan penelitian ini. Penulis mengucapkan terima kasih kepada Kepala Lembaga Penelitian dan Pengabdian Masyarakat Universitas Trunojoyo Madura yang telah berkontribusi dalam pembiayaan penelitian ini, Informan penelitian di Kabupaten Pamekasan, dan Pelbagai pihak yang telah membantu pelaksanaan penelitian ini.

\section{PERNYATAAN KONTRIBUSI PENULIS}

Dengan inikami menyatakan bahwa kontribusi masing-masing penulis terhadap pembuatan karya tulis adalah: Umi Hanik sebagai kontributor utama, Mutmainah sebagai kontributor anggota. Penulis menyatakan bahwa telah melampirkan surat pernyataan kontribusi penulis.

\section{DAFTAR PUSTAKA}

Bandura, A. (1986). Social Foundation of Thought and Action: A Social Cognitive Theory. Englewood Cliffs, NJ: Prentice-Hall.

Baekhaki, K., Kinseng, R. A. \& Soetarto, E. (2018). Korporatisasi Garam Rakyat: Dinamika Transisi Sosial, Ekonomi dan Ekologi Petambak Garam. Jurnal Sosiologi Pedesaan Sodality, 6(1).

Bouwsma, E. T. (1989). "Kekerasan di Masyarakat Madura." Dalam Huub de Jonge (ed.), Agama, Kebudayaan, dan Ekonomi: Studi-studi Interdisipliner tentang Masyarakat Madura, hal. 159-180. Jakarta: Rajawali Pers.
Branch, R. M. (2009). Instructional Design: The ADDIE Approach. New York: Springer Publishing.

Denzin, Norman K., \& Yvonna S. L. (1994). "Introduction: Entering the Field of Qualitative Research." Norman K. Denzin and Yvonna S. Lincoln (eds.), Handbook of Qualitative Research, pp. 1-17. Thousand Oaks, California: Sage Publications Inc.

Dick, W., \& Carey, L. (1996). The systematic design of instruction (4th ed.). New York: Harper Collins College Publisher.

Dinas Perikanan dan Kelautan Kabupaten Pamekasan. (2015). Profil Garam Rakyat. Pamekasan: Dinas Perikanan dan Kelautan Kabupaten Pamekasan.

Hanik, U. \& Mutmainah. (2018). Peran Model Social Learning dalam Meningkatkan Kompetensi Petani Garam di Kabupaten Pamekasan. Jurnal Sosiologi Simulacra,1(2).

Hotimah, K. (2019). Pewaris Budaya Kemiskinan dalam Kehidupan Petani Garam (Studi pada Kelompok Petani Garam di Desa Lembung, Kec. Galis, Kab. Pamekasan, Madura). Thesis Fakultas IImu Sosial dan Politik Universitas Airlangga.

Huberman, A. M. \& Miles, M.B. (1994). Data Management and Analysis Methods. Norman K. Denzin and Yvonna S. Lincoln (eds.), Handbook of Qualitative Research, pp. 428-444. Thousand Oaks, California: Sage Publications Inc.

Idi, A. (2013). Sosiologi Pendidikan: Individu, Masyarakat, dan Pendidikan. Jakarta: Raja Grafindo Persada.

Kementerian Kelautan dan Perikanan. (2015). Produksi Garam Indonesia. Dikutip dari https://statistik. kkp.go.id (diakses pada 4 Desember 2018).

Kementerian Kelautan dan Perikanan. (2019). Laut Masa Depan Bangsa, Mari Jaga Bersama. Siaran Pers Nomor SP204/SJ.04/VIII/2019. Dikutip dari https://kkp.go.id/artikel/12993 (diakses pada 22 Oktober 2020)

Kementerian Perindustrian. (2015). Pemerintah akan Tetap Impor Garam. Dikutip dari https://www. kemenperin.go.id (diakses pada 4 Desember 2018).

Koeswara, E. (1988). Agresi Manusia. Bandung: Eresco.

Maslow, A. H. (1994). Motivasi dan Kepribadian: Teori Motivasi dengan Pendekatan Hierarki Kebutuhan Manusia. Nurul Imam (terj.). Jakarta: Pustaka Binaman Pressindo.

Moleong, L. J. (2000). Metodologi Penelitian Kualitatif. Bandung: PT Remaja Rosdakarya.

Neuman, W. L. (2000). Social Research Methods. Boston: Allyn and Bacon.

Notoatmodjo, S. (1998). Pengembangan Sumber Daya Manusia. Jakarta: Rineka Cipta 
Permen KP Nomor PER.41/MEN/2011 tentang Pedoman Pelaksanaan Program Nasional Pemberdayaan Masyarakat Mandiri Kelautan dan Perikanan Tahun 2011 (Berita Negara Republik Indonesia Tahun 2011 Nomor 638).

Permen Perin Nomor 88/M-IND/PER/10/2014 tentang Perubahan Atas Peraturan Menteri Perindustrian Nomor 134/M-IND/PER/10/2009 tentang Peta Panduan (Road Map) Pengembangan Klaster Industri Garam.

Pervin, L. A. (2010). Psikologi Kepribadian: Teori and Penelitian. A. K. Anwar (terj.). Jakarta: Kencana.

Raco, J. R. (2010). Metode Penelitian Kualitatif: Jenis Karakteristik dan Keunggulannya. Jakarta: Gramedia Widiasarana Indonesia

Saksono, N. (2002). Studi Pengaruh Pencucian Garam terhadap Komposisi dan Stabilitas Yodium Garam Konsumsi. Jurnal Makara, Teknologi, 1(6)

Salim, Z. (2016). Tata Niaga dan 'Manisnya' Garam di Indonesia. In Zamroni Salim \& Ernawati Munadi (Ed.), Info Komoditi Garam, hal. 109-115. Jakarta: Al Mawardi Prima.

Spencer, L. \& Spencer, S. M. (1993). Competence at Work, Models For Superior Performance. Canada: John Wiley \& Sons, Inc.

Sugiono. (2017). Metode Penelitian: Kuantitatif, Kualitatif, dan R\&D. Bandung: Alfabeta.

Syah, M. (2013). Psikologi Pendidikan dengan Pendekatan Baru. Bandung: PT Remaja Rosdakarya.
Tim Bestekin. (2019). Pengujian Magnesium Pada Garam. Dikutip dari https://bestekin.com (diakses pada 2 April 2019).

Tirto. (2018). Pemeritah Targetkan Integrasi Lahan Petambak Garam 1.200 Hektare. Dikutip dari http://www.tirto.id (diakses pada 3 November 2018)

Wahyudi, M. (2015). Jurus Ombak dan Angin: Komunikasi Politik Si Pencari Ikan. In Surokim (ed.), Madura: Masyarakat, Budaya, Media dan Politik, hal. 2-16. Malang: Elmatera.

Yusuf, M. (2017). Metode Penelitian Kuantitatif, Kualitatif dan Gabungan. Jakarta: Kencana. 